\title{
Behavior and performance of sows fed different levels of fiber and reared in individual cages or collective pens
}

\author{
FÁBIO E.L. BUDIÑO ${ }^{1}$, RENATA F.N. VIEIRA ${ }^{2}$, SILVIO P. MELLO ${ }^{2}$ and KEILA M.R. DUARTE ${ }^{1}$ \\ ${ }^{1}$ Instituto de Zootecnia, Secretaria de Agricultura e Abastecimento \\ do Estado de São Paulo, 13460-000 Nova Odessa, SP, Brasil \\ ${ }^{2}$ Fundação Educacional de Ituverava, Faculdades Francisco Maeda - FAFRAM, \\ 14500-970 Ituverava, SP, Brasil
}

Manuscript received on June 9, 2014; accepted for publication on August 6, 2014

\begin{abstract}
Sixteen pregnant sows were used. The experimental design was completely randomized with a $2 \times 2$ factorial scheme consisting of two housing systems (individual cages and collective pens) and two diets (low [2.67\%] and high [13.14\%] level of crude fiber). Physiological, behavioral, environmental, and hormonal parameters were studied. In addition, the following productive and reproductive parameters were evaluated: weight gain, feed intake, feed conversion of the sow and piglets, number of piglets born dead and alive, number and weight at weaning, and backfat thickness of sows. Pregnant sows reared in collective pens and fed a highfiber diet exhibited better physiological responses, indicating greater comfort and better animal welfare. The environmental variables were close to the comfort zone of the animals. In addition to providing a more comfortable environment, housing pigs in collective pens reduced stereotypy, permitting the sows to express a more natural behavior. The high-fiber diet did not interfere with female productive performance. Tifton hay can therefore be indicated as an alternative for the formulation of sow diets to improve animal welfare.
\end{abstract}

Key words: swine, animal welfare, environmental enrichment, housing systems.

\section{INTRODUCTION}

Brazilian pig farming, like other agribusiness supply chains, has increased significantly over the last 14 years. This growth is noted when economic and social indicators, such as export volumes, participation in the world market, and number of direct and indirect jobs created, are analyzed (Gonçalves and Palmeira 2006).

Concern regarding food production is increasingly focused on the quality of the final product as well as environmental implications. This occurs

Correspondence to: Fábio Enrique Lemos Budiño

E-mail: fbudino@iz.sp.gov.br at a time when new technologies are emerging and new market requirements appear every day in parallel to the changing concepts of the population that demands a high-quality final product.

The types of intensive or industrial livestock production in which the animal is raised in confinement facilities throughout its life, often isolated from other animals and in a small space, have led to drastic alterations in normal animal behavior by creating different situations of stress. As a consequence, groups have emerged that are concerned with animal welfare and, in particular, with adequate housing and management solutions 
(Pandorfi et al. 2011). The issue of animal welfare has attracted much attention in technical, scientific, academic and production areas and has led to changes in current housing systems. Together with environmental and food safety issues, the maintenance of animal welfare is one of the three crucial challenges of modern agriculture.

The pig is a non-ruminant animal with a nonfunctional cecum. The use of forages or other bulky foods as a source of dietary fiber in pig feeding is not a new concept (Kambashi et al. 2014). However, in recent years dietary fiber has started to be used as an alternative source of energy in pig feeding, especially during the growth finishing of animals destined for slaughter and those destined for breeding (Gomes et al. 2006).

Foods rich in fibers more rapidly activate the satiety center in the brain of pigs through dilatation of the stomach wall and also slow down the digestion of ingredients by reducing the rate of gastrointestinal passage. As a consequence, animals submitted to quantitative food restriction remain for a shorter period of time in the stress condition caused by the feeling of hunger (Che et al. 2011).

The objective of the present experiment was to analyze the effect of different dietary levels of crude fiber and different housing systems on the behavior and reproductive performance of sows.

\section{MATERIALS AND METHODS}

The present study was approved by the animal welfare committee of the Institute of Animal Science, São Paulo, Brazil.

The experiment was conducted at the Pig Farming Sector of Sítio das Acácias, Faculdade Dr. Francisco Maeda, located in the town of Ituverava, São Paulo, Brazil (20²0’30" S and 4747’30” W, $690 \mathrm{~m}$ ). The mean annual temperature in the region is $25.5^{\circ} \mathrm{C}$.

The treatments considered two essential factors for the evaluation of sow welfare: the housing system and the source of dietary fiber as bulky food. Sixteen crossbred sows ( $1 / 2$ Landrace $x 1 / 2$ Large White) of the same parity order were used, corresponding to four animals per treatment. The sows were housed in individual cages (traditional confinement system) measuring $1.4 \mathrm{~m}^{2}(0.70 \times 2.0 \mathrm{~m})$ and in collective pens measuring $12 \mathrm{~m}^{2}(3.0 \times 4.0 \mathrm{~m})$, with wood shavings as bedding.

By day 35 of gestation, the effect of two diets, one with a low $(\mathrm{LF}=2.67 \%)$ and one with a high $(\mathrm{HF}=13.14 \%)$ content of crude fiber, on female behavior and reproductive performance was evaluated. After the period of gestation, the sows were housed in farrowing crates equipped with automatic feeders and drinking fountains and electrically heated floor mats.

The experimental diets were formulated according to Gomes et al. (2006) and their percent composition is shown in Table I. From day 35 to day 90 of gestation the sows were fed dry ration $(2.0 \mathrm{~kg})$ once a day, at $6: 00 \mathrm{~h}$, with water available ad libitum. By day 90, the animals started to receive $2.3 \mathrm{~kg}$ ration/day. At the end of gestation considering the last week as the expected farrowing date, the sows were transferred to the maternity pen in farrowing crates where they remained for 21 days, i.e., until weaning of the piglets.

The following parameters were evaluated to better discuss the behavior of sows reared in the two housing systems and fed the two diets: ambient temperature, black-globe temperature (BGT), concrete floor temperature, bedding temperature, and relative humidity $(\mathrm{RH})$. The environmental variables (ambient temperature, BGT and RH) were recorded weekly at 7:30,11:30 and 16:30 h throughout gestation using two HOBO data loggers. The equipment was installed inside the farm in the center of the pen at a distance of $1.30 \mathrm{~m}$ from the floor. Floor and bedding temperatures were collected with a digital infrared thermometer with laser sight (Instrutherm, model TI 870) at $5 \mathrm{~cm}$ from the site in a clean area. The calibrated emissivity for data collection was 0.90 in relation to the concrete. To better determine the thermal efficiency of the facilities, the environmental 
TABLE I

Composition of experimental diet. (\% as-fed basis)

\begin{tabular}{lcc}
\hline \multicolumn{1}{c}{ Ingredients } & LF & HF \\
\hline Corn, $7.8 \%$ CP & 80.54 & 53.74 \\
Soybean meal, $45 \%$ CP & 17.02 & 33.00 \\
Tifton hay & - & 11.00 \\
Bicalcic Phosphate & 1.15 & 1.45 \\
Limestone & 0.59 & 0.11 \\
Salt & 0.50 & 0.50 \\
Mineral and vitamin supplement * & 0.20 & 0.20 \\
\hline Chemical content (analyzed values) & & \\
\hline Metabolizable energy, MJ.kg ${ }^{-1}$ & 13.39 & 11.50 \\
Crude Fiber & 2.67 & 13.14 \\
ADF & 2.75 & 16.52 \\
NDF & 9.17 & 26.28 \\
Ether extract & 2.92 & 2.83 \\
Crude Protein & 14.66 & 14.00 \\
Total lysine & 0.70 & 0.72 \\
Total Methionine + cystine & 0.52 & 0.47 \\
Total methionine & 0.24 & 0.22 \\
Total threonine & 0.56 & 0.53 \\
Total tryptophan & 0.16 & 0.15 \\
Calcium & 0.60 & 0.60 \\
Total phosphorus & 0.50 & 0.50 \\
\hline * & &
\end{tabular}

* Guaranteed level per kg ration: vitamin A-4,000 IU; vitamin D3 - $220 \mathrm{IU}$; vitamin E - $22 \mathrm{mg}$; vitamin $\mathrm{K}-0.5 \mathrm{mg}$; vitamin $\mathrm{B} 2-3.75 \mathrm{mg}$; vitamin B12 - $20 \mu \mathrm{g}$; calcium pantothenate $12 \mathrm{mg}$; niacin - $20 \mathrm{mg}$; choline - $60 \mathrm{mg}$; iodine - $140 \mu \mathrm{g}$; selenium - $300 \mu \mathrm{g}$; manganese - $10 \mathrm{mg}$; zinc - $100 \mathrm{mg}$; copper $-10 \mathrm{mg}$; iron - $99 \mathrm{mg}$. HF: high fiber; LF: low fiber.

variables measured in the environments studied were used to calculate the black globe temperature-humidity index (BGTHI) and specific enthalpy ( $\left.\mathrm{kJ} \cdot \mathrm{kg}^{-1}\right)$ using the equations proposed by Buffington et al. (1981) and Albright (1990), respectively.

The skin temperature of the animals was measured with a digital infrared thermometer with laser sight (Instrutherm, model TI 870) calibrated for the usual emissivity of animals (0.97). The site of measurement was the height at withers at a distance of $5 \mathrm{~cm}$ from the animal. The respiratory rate of sows was measured visually by counting flank movements per minute using a digital chronometer. All characteristics were recorded weekly at 7:30, 12:30 and 16:30 h.
Behavioral assessments were performed from day 35 of gestation until the last week before farrowing as described by Gentilini et al. (2003). The animals were observed over a period of $3 \mathrm{~h}$ at intervals of 15 minutes, starting 30 minutes after the last meal (from 6:30 to $9: 30 \mathrm{~h}$ ). The following positions adopted by the sows were evaluated: lateral recumbency, ventral recumbency sitting, or standing. The following behaviors shown at the time of assessment were also analyzed: absence of stereotypy, vacuum chewing, floor licking, trough licking, bar biting, rooting, drinking water, and sleeping.

Saliva was collected for cortisol measurement in the last week of gestation considering that on average seven days were left until the expected farrowing date. Salivary samples were collected 30 minutes after the last meal with a salivette inserted in the animal's mouth for three minutes. Next, saliva was collected from the cotton by pressure into a 1.5$\mathrm{mL}$ Eppendorf tube and stored at $-20^{\circ} \mathrm{C}$. Salivary cortisol concentration was determined with the Salimetrics ELISA kit and the results were read in a Biotek E800 X microplate reader.

Animal performance and production were evaluated based on the following variables: (a) breeding and farrowing weights; (b) weight gain; (c) body condition score rated by a trained examiner on a scale from 1 to 5 , where $1=$ very thin, $2=$ thin, $3=$ normal, 4 = fat, and 5 = very fat; (d) backfat thickness at breeding and farrowing, measured by ultrasound (Microem, MTU-100) at a distance of $5.5 \mathrm{~cm}$ from the lumbar mid-line of the last rib on both sides (Young and Aherne 2005); (e) number of piglets at birth and weaning; (f) mortality rate; (g) piglet weight from birth to weaning, and (h) feed intake and feed conversion of sows from breeding to farrowing.

A completely randomized design with different numbers of repetitions and a $2 \times 2$ factorial scheme consisting of two housing systems (individual cages and collective pens with bedding) and two diets (LF and HF), with repeated measures of time (7:30, 11:30 and 16:30), was used for general analysis of 
the data. The experimental unit consisted of one sow. The environmental and physiological variables were submitted to repeated-measures (time) analysis of variance using the MIXED procedure of the Statistical Analysis System (SAS) ${ }^{\circledR}$ program (SAS Institute 2001) in order to determine the structure of the variance and covariance matrix. A level of significance of $5 \%$ was adopted for analysis of variance. Significant interactions were identified according to the factors involved. Means of the main effects and interactions were compared by the Tukey-Kramer test. The Tukey test was adopted for the analysis of performance and hormonal parameters $(\mathrm{P}<0.01)$. Behavioral variables were submitted to frequency analysis.

\section{RESULTS AND DISCUSSION}

No significant differences in ambient temperature, BGT or RH were observed between sows housed in individual cages and collective pens or between sows fed LF and HF diets. Mean ambient temperature ranged from 25.47 to $26.18^{\circ} \mathrm{C}$, mean BGT from 26.83 to $26.94^{\circ} \mathrm{C}$, and mean $\mathrm{RH}$ from 74.07 to $76.33 \%$.

Mean ambient temperature $\left(22.52^{\circ} \mathrm{C}\right)$ and $\operatorname{BGT}\left(23.81^{\circ} \mathrm{C}\right)$ were lower at $7: 30 \mathrm{~h}$, irrespective of housing system and diet of pregnant sows. However, regardless of the housing system and diet offered, the variation in RH inside the facility was within the limits of 55 to $85 \%$ reported to be adequate by Sant'Anna et al. (2010). Pandorfi et al. (2008) found RH of $70.14 \%$ and $70.48 \%$ in individual and collective pens of pregnant sows values similar to those obtained in the present study.

No significant differences in BGTHI (Table II), enthalpy (Table III) or floor temperature (Table IV) were observed between the housing systems or between the diets offered to pregnant sows (P $>0.05)$. The mean BGTHI values were 61.29 and 61.03 for individual and collective pens, respectively, and 61.26 and 61.07 for the LF and HF diets. However, there were significant differences in BGTHI between evaluation times for both housing system and diet; higher values were observed at 11:30 h. Pandorfi et al. (2008) reported BGTHI of 73.40 and 73.56 for sows housed in collective and individual pens, respectively, values higher than those obtained in the present study.

Mean enthalpies (h) were 81.34 and 76.68 $\mathrm{kJ} . \mathrm{kg}^{-1}$ for individual cages and collective pens, respectively, and 80.42 and $79.60 \mathrm{~kJ}^{\mathrm{kg}} \mathrm{kg}^{-1}$ for the LF and HF diets. However, enthalpy values were significantly higher at $7: 30 \mathrm{~h}$ for the different housing systems and diets, decreasing at 11:30 and 17:00h. Lower values have been reported by Pandorfi et al. (2008), with enthalpies of 63.47 and $62.02 \mathrm{~kJ} \mathrm{~kg}^{-1}$ for collective and individual pens, respectively. According to this author, an enthalpy of $70 \mathrm{~kJ} . \mathrm{kg}^{-1}$ provides greater comfort for animals.

TABLE II

Mean and standard error of the mean of BGTHI according to housing system, diet and evaluation time.

\begin{tabular}{cccc}
\hline \multicolumn{5}{c}{ BGTHI } \\
\hline \multirow{2}{*}{ Diet } & \multicolumn{4}{c}{ IC } & CP & Mean \\
\cline { 2 - 4 } LF & $61.32 \pm 0.71 \mathrm{aA}$ & $61.21 \pm 0.50 \mathrm{aA}$ & $61.26 \pm 0.43$ \\
HF & $61.27 \pm 0.56 \mathrm{aA}$ & $60.86 \pm 0.64 \mathrm{aA}$ & $61.07 \pm 0.43$ \\
Mean & $61.29 \pm 0.45$ & $61.03 \pm 0.41$ \\
\hline \multirow{4}{c}{ System } \\
\cline { 2 - 4 } Hour & IC & CP \\
\hline 7:30 & $60.27 \pm 0.48 \mathrm{aB}$ & $59.37 \pm 0.43 \mathrm{aC}$ & $59.82 \pm 0.32$ \\
$11: 30$ & $62.92 \pm 0.49 \mathrm{aA}$ & $63.34 \pm 0.44 \mathrm{aA}$ & $63.13 \pm 0.33$ \\
$17: 00$ & $60.69 \pm 0.49 \mathrm{aB}$ & $60.39 \pm 0.43 \mathrm{aB}$ & $60.54 \pm 0.33$ \\
Mean & $61.29 \pm 0.45$ & $61.03 \pm 0.41$ \\
\hline \multirow{4}{*}{ Diet } \\
\cline { 2 - 4 } Hour & LF & HF & Mean \\
\hline $7: 30$ & $59.96 \pm 0.45 \mathrm{aB}$ & $59.69 \pm 0.46 \mathrm{aB}$ & $59.82 \pm 0.32$ \\
$11: 30$ & $63.11 \pm 0.47 \mathrm{aA}$ & $63.15 \pm 0.46 \mathrm{aA}$ & $63.13 \pm 0.33$ \\
$17: 00$ & $60.72 \pm 0.47 \mathrm{aB}$ & $60.36 \pm 0.46 \mathrm{aB}$ & $60.54 \pm 0.33$ \\
Mean & $61.20 \pm 0.43$ & $61.07 \pm 0.43$ \\
\hline
\end{tabular}

Means in the same row followed by different lowercase letters and means in the same column followed by different uppercase letters differ from one another (Tukey-Kramer test, $\mathrm{P}<0.05)$. IC: individual cage; $\mathrm{CP}$ : collective pen; HF: high fiber; LF: low fiber. 
TABLE III

Mean and standard error of the mean of enthalpy (h) according to housing system, diet and evaluation time.

\begin{tabular}{|c|c|c|c|}
\hline \multicolumn{4}{|c|}{ Enthalpy (h) kJ.kg ${ }^{-1}$} \\
\hline \multirow{2}{*}{ Diet } & \multicolumn{2}{|c|}{ System } & \multirow[b]{2}{*}{ Mean } \\
\hline & IC & $\mathbf{C P}$ & \\
\hline LF & $81.47 \pm 2.55 \mathrm{aA}$ & $79.35 \pm 1.80 \mathrm{aA}$ & $80.42 \pm 1.56$ \\
\hline $\mathrm{HF}$ & $81.20 \pm 2.01 \mathrm{aA}$ & $78.00 \pm 2.33 \mathrm{aA}$ & $79.60 \pm 1.54$ \\
\hline Mean & $81.34 \pm 1.63$ & $78.68 \pm 1.47$ & \\
\hline \multirow{2}{*}{ Hour } & \multicolumn{2}{|c|}{ System } & \\
\hline & IC & $\mathbf{C P}$ & Mean \\
\hline $7: 30$ & $87.53 \pm 1.65 \mathrm{aA}$ & $85.16 \pm 1.50 \mathrm{aA}$ & $86.34 \pm 1.11$ \\
\hline $11: 30$ & $81.22 \pm 1.66 \mathrm{aB}$ & $77.44 \pm 1.50 \mathrm{aB}$ & $79.33 \pm 1.11$ \\
\hline $17: 00$ & $75.27 \pm 1.66 \mathrm{aC}$ & $73.44 \pm 1.50 \mathrm{aC}$ & $74.35 \pm 1.11$ \\
\hline Mean & $81.34 \pm 1.63$ & $78.68 \pm 1.47$ & \\
\hline \multirow{2}{*}{ Hour } & \multicolumn{2}{|c|}{ Diet } & \\
\hline & LF & HF & Mean \\
\hline $7: 30$ & $86.45 \pm 1.58 \mathrm{aA}$ & $86.23 \pm 1.57 \mathrm{aA}$ & $86.34 \pm 1.11$ \\
\hline $11: 30$ & $80.37 \pm 1.59 \mathrm{aB}$ & $78.29 \pm 1.57 \mathrm{aB}$ & $79.33 \pm 1.11$ \\
\hline $17: 00$ & $74.42 \pm 1.59 \mathrm{aC}$ & $74.29 \pm 1.57 \mathrm{aC}$ & $74.35 \pm 1.11$ \\
\hline Mean & $80.42 \pm 1.56$ & $79.60 \pm 1.54$ & \\
\hline
\end{tabular}

Means in the same row followed by different lowercase letters and means in the same column followed by different uppercase letters differ from one another (Tukey-Kramer test, $\mathrm{P}<0.05$ ). IC: individual cage; CP: collective pen; HF: high fiber; LF: low fiber.

TABLE IV

Mean and standard error of the mean of floor temperature $\left({ }^{\circ} \mathrm{C}\right)$ according to housing system, diet and evaluation time.

\begin{tabular}{|c|c|c|c|}
\hline \multicolumn{4}{|c|}{ Floor temperature $\left({ }^{\circ} \mathrm{C}\right)$} \\
\hline \multirow{2}{*}{ Diet } & \multicolumn{2}{|c|}{ System } & \multirow[b]{2}{*}{ Mean } \\
\hline & IC & $\mathbf{C P}$ & \\
\hline LF & $26.64 \pm 0.75 \mathrm{aA}$ & $25.67 \pm 0.53 \mathrm{aA}$ & $26.15 \pm 0.46$ \\
\hline $\mathrm{HF}$ & $26.64 \pm 0.59 \mathrm{aA}$ & $25.94 \pm 0.68 \mathrm{aA}$ & $25.79 \pm 0.45$ \\
\hline Mean & $26.14 \pm 0.48$ & $25.81 \pm 0.43$ & \\
\hline \multirow{2}{*}{ Hour } & \multicolumn{2}{|c|}{ System } & \\
\hline & IC & $\mathbf{C P}$ & Mean \\
\hline $7: 30$ & $25.80 \pm 0.50 \mathrm{aB}$ & $24.47 \pm 0.46 \mathrm{aC}$ & $25.13 \pm 0.34$ \\
\hline $11: 30$ & $25.95 \pm 0.51 \mathrm{aAB}$ & $26.90 \pm 0.46 \mathrm{aA}$ & $26.43 \pm 0.34$ \\
\hline $17: 00$ & $26.63 \pm 0.51 \mathrm{aA}$ & $26.05 \pm 0.46 \mathrm{aB}$ & $26.36 \pm 0.34$ \\
\hline Mean & $26.14 \pm 0.48$ & $25.81 \pm 0.43$ & \\
\hline \multirow{2}{*}{ Hour } & \multicolumn{2}{|c|}{ Diet } & \\
\hline & LF & HF & Mean \\
\hline $7: 30$ & $25.17 \pm 0.48 \mathrm{aB}$ & $25.10 \pm 0.48 \mathrm{aB}$ & $25.13 \pm 0.34$ \\
\hline $11: 30$ & $26.46 \pm 0.49 \mathrm{aA}$ & $26.39 \pm 0.48 \mathrm{aA}$ & $26.43 \pm 0.34$ \\
\hline $17: 00$ & $26.83 \pm 0.49 \mathrm{aA}$ & $25.89 \pm 0.48 \mathrm{aAB}$ & $26.36 \pm 0.34$ \\
\hline Mean & $26.15 \pm 0.46$ & $25.79 \pm 0.45$ & \\
\hline
\end{tabular}

Means in the same row followed by different lowercase letters and means in the same column followed by different uppercase letters differ from one another (Tukey-Kramer test, $\mathrm{P}<0.05$ ). IC: individual cage; CP: collective pen; HF: high fiber; LF: low fiber.
The mean floor surface temperatures were 26.14 and $25.81{ }^{\circ} \mathrm{C}$ for individual cages and collective pens, respectively, and 26.16 and $25.79^{\circ} \mathrm{C}$ for the LF and HF diets. Significant differences in mean floor temperature were observed between evaluation times for the different housing systems and diets. In individual cages, the floor temperature was lower at 7:30 and 11:30h, increasing thereafter (17:00h). In contrast, in collective pens with bedding a lower temperature was only observed at 7:30h. The temperature increased thereafter, possibly because of the higher ambient temperature and greater fermentation of the bedding material, with a consequent increase in the surface temperature of the bed.

Corrêa et al. (2008) evaluated different heights $(0.50$ and $0.25 \mathrm{~cm})$ of rice husk bedding and concrete floor in pens of growing and finishing pigs and found floor temperatures of $26.1,24.5$ and $18.0^{\circ} \mathrm{C}$, respectively. These values are similar to those observed in the present study in collective pens using wood shaving as bedding; however, the values obtained for pens with concrete floor are lower than those found here. Cordeiro et al. (2007), studying the effects of different housing systems on ambient thermal comfort and productive performance of pigs during spring, observed that concrete flooring generally provided better thermal comfort during the finishing phase when compared to the use of wood shavings or rice husk as bedding. This finding might be related to the fact that the higher temperatures observed for wood shaving beds are probably caused by the generation of normal heat during the composting process. In addition, concrete floor has lower thermal inertia and retains less heat, characteristics that contribute to greater thermal comfort for the animals.

A significant difference in respiratory rate (Table V) was observed between treatments, i.e., between housing systems and diets. Sows housed in individual cages and fed the LF diet presented a higher mean respiratory rate $\left(60.36\right.$ breaths. $\left.\mathrm{min}^{-1}\right)$ than sows housed in collective pens and fed the HF $\operatorname{diet}\left(39.12\right.$ breaths. $\mathrm{min}^{-1}$ ). 
TABLE V

Mean and standard error of the mean of respiratory rate of pregnant sows according to housing system, diet and evaluation time.

\begin{tabular}{|c|c|c|c|}
\hline \multicolumn{4}{|c|}{ Rate respiratory $^{\# 1}$} \\
\hline \multirow{2}{*}{ Diet } & \multicolumn{2}{|c|}{ System } & \multirow[b]{2}{*}{ Mean } \\
\hline & IC & $\mathbf{C P}$ & \\
\hline $\mathrm{LF}$ & $\begin{array}{c}60.36 \pm 4.78 \\
(1.64 \pm 0.03) \mathrm{aA}\end{array}$ & $\begin{array}{c}43.20 \pm 3.29 \\
(1.57 \pm 0.02) \mathrm{bA}\end{array}$ & $\begin{array}{l}51.78 \pm 2.90 \\
(1.64 \pm 0.03)\end{array}$ \\
\hline $\mathrm{HF}$ & $\begin{array}{c}40.55 \pm 3.72 \\
(1.52 \pm 0.02) \mathrm{aB}\end{array}$ & $\begin{array}{c}39.12 \pm 4.28 \\
(1.56 \pm 0.03) \mathrm{aA}\end{array}$ & $\begin{array}{l}39.84 \pm 2.84 \\
(1.55 \pm 0.03)\end{array}$ \\
\hline Mean & $\begin{array}{l}50.46 \pm 3.03 \\
(1.64 \pm 0.03) \\
\end{array}$ & $\begin{array}{l}41.16 \pm 2.70 \\
(1.55 \pm 0.03) \\
\end{array}$ & \\
\hline \multirow{2}{*}{ Hour } & \multicolumn{2}{|c|}{ System } & \\
\hline & IC & $\mathbf{C P}$ & Mean \\
\hline $7: 30$ & $\begin{array}{c}64.70 \pm 3.79 \\
(1.78 \pm 0.04) \mathrm{aA}\end{array}$ & $\begin{array}{c}44.15 \pm 3.45 \\
(1.60 \pm 0.03) \mathrm{bA}\end{array}$ & $\begin{array}{l}54.42 \pm 2.55 \\
(1.69 \pm 0.03)\end{array}$ \\
\hline $11: 30$ & $\begin{array}{c}38.50 \pm 3.92 \\
(1.50 \pm 0.04) \mathrm{AC}\end{array}$ & $\begin{array}{c}38.48 \pm 3.46 \\
(1.51 \pm 0.03) \mathrm{aA}\end{array}$ & $\begin{array}{l}38.49 \pm 2.59 \\
(1.50 \pm 0.03)\end{array}$ \\
\hline $16: 30$ & $\begin{array}{c}48.17 \pm 3.92 \\
(1.63 \pm 0.04) \mathrm{aB}\end{array}$ & $\begin{array}{c}40.86 \pm 3.44 \\
1.55 \pm 0.03) \mathrm{aA}\end{array}$ & $\begin{array}{l}44.51 \pm 2.58 \\
(1.59 \pm 0.03)\end{array}$ \\
\hline Média & $\begin{array}{l}50.46 \pm 3.03 \\
(1.64 \pm 0.03)\end{array}$ & $\begin{array}{l}41.16 \pm 2.70 \\
(1.55 \pm 0.03)\end{array}$ & \\
\hline \multirow{2}{*}{ Hour } & \multicolumn{2}{|c|}{ Diet } & \\
\hline & LF & HF & Mean \\
\hline $7: 30$ & $\begin{array}{c}60.94 \pm 3.54 \\
(1.74 \pm 0.04) \mathrm{aA}\end{array}$ & $\begin{array}{c}47.91 \pm 3.70 \\
(1.64 \pm 0.04) \mathrm{aA}\end{array}$ & $\begin{array}{l}54.42 \pm 2.55 \\
(1.69 \pm 0.03)\end{array}$ \\
\hline $11: 30$ & $\begin{array}{c}44.57 \pm 3.75 \\
(1.56 \pm 0.04) \mathrm{aB}\end{array}$ & $\begin{array}{c}32.41 \pm 3.63 \\
(1.45 \pm 0.04) \mathrm{aB}\end{array}$ & $\begin{array}{l}38.49 \pm 2.59 \\
(1.50 \pm 0.03)\end{array}$ \\
\hline $16: 30$ & $\begin{array}{c}49.83 \pm 3.72 \\
(1.63 \pm 0.04) \mathrm{aAB}\end{array}$ & $\begin{array}{c}39.20 \pm 3.63 \\
(1.55 \pm 0.03) \mathrm{aAB}\end{array}$ & $\begin{array}{l}44.51 \pm 2.58 \\
(1.59 \pm 0.03)\end{array}$ \\
\hline Mean & $\begin{array}{l}51.78 \pm 2.90 \\
(1.64 \pm 0.03)\end{array}$ & $\begin{array}{l}39.84 \pm 2.84 \\
(1.55 \pm 0.03)\end{array}$ & \\
\hline
\end{tabular}

Means in the same row followed by different lowercase letters and means in the same column followed by different uppercase letters differ from one another (Tukey-Kramer test, $\mathrm{P}<0.05)^{1}$. Means in parentheses are Log $\mathrm{X}^{\#}$ transformed - statistics used for transformed data. IC: individual cage; $\mathrm{CP}$ : collective pen; HF: high fiber; LF: low fiber.

Evaluation of mean respiratory rate over time in sows housed in individual cages revealed significant differences, with a higher rate at $7: 30 \mathrm{~h}$ $\left(64.70\right.$ breaths. $\left.\mathrm{min}^{-1}\right)$ which decreased at $11: 30 \mathrm{~h}$ (38.50 breaths. $\mathrm{min}^{-1}$ ) and increased again at $16: 30 \mathrm{~h}$ (48.17 breaths $\min ^{-1}$ ). No significant differences in mean respiratory rate were observed for sows housed in collective pens; however, the respiratory rate followed the same trend over time, i.e., a higher rate at $7: 30 \mathrm{~h}\left(44.15\right.$ breaths. $\left.\mathrm{min}^{-1}\right)$, an intermediate rate at $11: 30 \mathrm{~h}\left(38.48\right.$ breaths. $\left.\mathrm{min}^{-1}\right)$, and an increase in the afternoon (40.86 breaths.min ${ }^{-1}$ ). In addition, sows housed in collective pens presented a lower mean respiratory at 7:30h $\left(44.15\right.$ breaths. $\left.\mathrm{min}^{-1}\right)$ than those housed in individual cages ( 64.70 breaths. $\left.\min ^{-1}\right)$. This finding is probably due to the fact that the space of collective pens provides greater comfort for the animals than that of individual cages. The respiratory rate was also influenced by the diets at the different evaluation times, showing the same trend as that observed for the different housing conditions, i.e., a higher rate in the morning, intermediate at 11:30h, and increasing in the afternoon. The higher respiratory rate observed in the morning is probably due to the greater agitation of sows immediately after feeding, whereas the higher rate in the afternoon can be explained by the higher ambient temperature inside the barn.

The mean respiratory rates were found to be above the comfort zone of animals of this category, irrespective of housing system and diet. Pregnant sows in the zone of thermal comfort have a respiratory rate of 15 to 20 breaths. $\mathrm{min}^{-1}$. According to Mendes et al. (2013), breathing movements can increase by 22 to $100 \%$ as a function of the thermal environment. Pandorfi et al. (2008) studied pregnant sows reared in individual and collective pens and observed respiratory rates of 43 and 36 breaths. min $^{-1}$, rates similar to those observed in the present study. According to this author, when the respiratory rate is high, the ambient temperature is close to the body temperature, heat is stored in the organism, and the body temperature increases above the normal range. This response is the result of direct stimulation of the heat center in the hypothalamus, which sends impulses to the cardiorespiratory system in an attempt to eliminate heat by evaporation through an increase in respiratory rate.

Mean skin temperatures (Table VI) differed significantly between the two diets offered. Animals fed the LF and HF diets presented a skin temperature of 34.20 and $33.36^{\circ} \mathrm{C}$, respectively. 
Skin temperature was lower at 7:30h, intermediate at 11:30h, and decreased in the afternoon. Mendes et al. (2013) evaluated the skin temperature of lactating dams reared under natural ventilation and observed temperatures ranging from 30.83 to $33.16^{\circ} \mathrm{C}$, values similar to those found in the present study.

TABLE VI

Mean and standard error of the mean of skin temperature of pregnant sows according to housing system, diet and evaluation time.

\begin{tabular}{cccc}
\hline \multicolumn{4}{c}{ Skin temperature $\left({ }^{\circ} \mathbf{C}\right)$} \\
\hline \multirow{2}{*}{ Siet } & \multicolumn{3}{c}{ System } \\
\cline { 2 - 4 } & IC & CP & Mean \\
\hline LF & $34.25 \pm 0.46$ & $34.14 \pm 0.32$ & $34.20 \pm 0.28 \mathrm{~A}$ \\
HF & $33.41 \pm 0.36$ & $33.32 \pm 0.41$ & $33.36 \pm 0.27 \mathrm{~B}$ \\
Mean & $33.83 \pm 0.29 \mathrm{a}$ & $33.73 \pm 0.26 \mathrm{a}$ \\
\hline \multirow{4}{c}{ System } \\
\cline { 2 - 4 } Hour & IC & CP \\
\hline 7:30 & $33.79 \pm 0.32 \mathrm{aAB}$ & $33.22 \pm 0.29 \mathrm{aB}$ & $33.51 \pm 0.21$ \\
$11: 30$ & $34.28 \pm 0.33 \mathrm{aA}$ & $34.41 \pm 0.29 \mathrm{aA}$ & $34.34 \pm 0.22$ \\
$16: 30$ & $33.42 \pm 0.33 \mathrm{aB}$ & $33.55 \pm 0.29 \mathrm{aB}$ & $33.49 \pm 0.22$ \\
Mean & $33.83 \pm 0.29$ & $33.73 \pm 0.26$ \\
\hline \multirow{4}{*}{ Diet } \\
\cline { 2 - 4 } Hour & LF & HF & Mean \\
\hline 7:30 & $33.91 \pm 0.30 \mathrm{aB}$ & $33.10 \pm 0.31 \mathrm{aB}$ & $33.51 \pm 0.21$ \\
$11: 30$ & $34.74 \pm 0.31 \mathrm{aA}$ & $33.94 \pm 0.30 \mathrm{aA}$ & $34.34 \pm 0.22$ \\
$16: 30$ & $33.93 \pm 0.31 \mathrm{aB}$ & $33.05 \pm 0.30 \mathrm{aB}$ & $33.49 \pm 0.22$ \\
Mean & $34.20 \pm 0.28$ & $33.36 \pm 0.27$ \\
\hline
\end{tabular}

Means in the same row followed by different lowercase letters and means in the same column followed by different uppercase letters differ from one another (Tukey-Kramer test, $\mathrm{P}<0.05)$. IC: individual cage; $\mathrm{CP}$ : collective pen; HF: high fiber; LF: low fiber.

Table VII shows the variation in the posture of sows reared in the different housing systems and receiving the different diets, as well as the mean frequency and percentage of time spent in ventral or lateral recumbency, sitting, and standing. It should be noted that each behavioral posture is always associated with one of the behaviors shown in Table VIII.

According to Cassar et al. (2008), the critical time when aggression between pigs increases is during feeding due to the competition for food
TABLE VII

Mean frequency and percentage of the variation in the posture of pregnant sows according to housing system and diet.

\begin{tabular}{ccccc}
\hline \multirow{2}{*}{ Posture } & \multicolumn{2}{c}{ System } & \multicolumn{2}{c}{ Diet } \\
\cline { 2 - 6 } & IC & CP & LF & HF \\
\hline LR & $(150) 24.59$ & $(247) 23.77$ & $(145) 20.42$ & $(252) 26.33$ \\
VR & $(292) 47.87$ & $(396) 37.46$ & $(284) 40.00$ & $(404) 42.22$ \\
Sitting & $(144) 23.61$ & $(371) 35.10$ & $(240) 33.80$ & (275) 28.74 \\
Standing & (24) 3.93 & (43) 4.07 & (41) 5.77 & (26) 2.72 \\
\hline
\end{tabular}

IC: individual cage; CP: collective pen; LF: low fiber; HF: high fiber; LR: lateral recumbency; VR: ventral recumbency. The number of observations is given in parentheses.

in the troughs or on the floor. However, since the animals were fed once a day using a controlled feeding system, behavioral observations were only made 30 minutes after feeding.

Analysis of the lateral recumbent position according to housing system and dietary fiber level showed that the percentages of time spent in this position were similar, $24.59 \%$ for individual cages, $23.77 \%$ for collective pens, $20.42 \%$ for the LF diet, and $26.33 \%$ for the HF diet. The percentage of time spent in ventral recumbency was $47.87 \%$ in collective pens and $37.46 \%$ in individual cages. These percentages were $40.0 \%$ and $42.22 \%$ for sows fed the LF and HF diets, respectively. The percentage of time spent standing, corresponding to the time of movement of the sows in collective pens and change of posture in individual cages, was $35.10 \%$ and 23.61 , respectively, demonstrating the greater availability of space in the former treatment (Anil et al. 2002). The percentage of time spent standing was higher for sows fed the LF diet (33.8\%) compared to those receiving the HF diet (28.74\%). A similar percentage of time spent sitting was observed for animals reared in individual (3.93\%) and collective pens (4.07\%). However, this percentage was $5.77 \%$ for sows fed the LF diet and $2.72 \%$ for sows receiving the HF diet.

Gentilini et al. (2003), evaluating pregnant sows housed in cages and collective pens and fed HF and LF diets, observed a lower frequency of the standing 
position and a higher frequency of the lying position in animals housed in cages and fed the HF diet 10 minutes after the end of morning feeding, and a lower frequency of the sitting position 30 minutes after morning feeding when compared to the LF diet. The housing system influenced standing and lying posture 10 minutes after morning feeding, irrespective of diet. The changes in posture or behavior observed 10 and/ or 30 minutes after morning feeding of sows housed in cages and fed a HF diet suggest that this type of diet is more important for animals kept in small places where movement is limited, increasing restlessness.

Cassar et al. (2008) observed that the time spent lying was increased in sows submitted to feed restriction when supplemented with bulky food. A reduction in standing activity has been reported when different fiber components were included in the diet, such as chopped straw, wheat bran and corn cob (Robert et al. 1997). The number of postural changes also decreased with supplementation of the diets with fibrous ingredients, with the observation of a strong effect when the sows received a diet containing rice husk compared to wheat bran and corn cob (Robert et al. 1997). Che et al. (2011) reported a beneficial effect of increasing plant cell wall content in the gestation diet of multiparous sows, expressed as a reduction in the time spent in the standing position and an increase in the time spent in the lying position.

Pandorfi et al. (2008), evaluating pregnant sows housed in individual and collective pens, observed a similar percentage of time spent in lateral recumbency for the two treatments $(25.46 \%$ and $25.23 \%$, respectively). The percentage of time spent in ventral recumbency was $10.76 \%$ for animals housed in collective pens and $12.15 \%$ for animals housed in individual pens, whereas the percentage of time spent standing was $13.43 \%$ and $7.87 \%$, respectively.

The frequency of absent stereotypy (Table VIII) was $34.1 \%$ and $32.8 \%$ in sows housed in individual and collective pens, respectively, with a small difference between housing systems. This behavior was also observed most of the time for sows fed the LF (37.75\%) and HF (29.96\%) diets. The frequency of the sleeping behavior was lower among sows housed in individual cages (18.2\%) and fed the LF diet (18.87\%) compared to those kept in collective pens $(28.17 \%)$ and fed the HF diet $(28.71 \%)$

\section{TABLE VIII}

Mean frequency and percentage of behavioral variation and stereotypy of pregnant sows according to housing system and diet.

\begin{tabular}{ccccc}
\hline \multirow{2}{*}{ Behavior } & \multicolumn{2}{c}{ System } & \multicolumn{2}{c}{ Diet } \\
\cline { 2 - 6 } & IC & CP & LF & HF \\
\hline AS & $(208) 34.10$ & $(347) 32.80$ & $(268) 37.75$ & $(287) 29.96$ \\
DW & $(29) 4.75$ & $(53) 5.01$ & $(42) 5.92$ & (40) 4.18 \\
Sleeping & $(111) 18.20$ & $(298) 28.17$ & $(134) 18.87$ & $(275) 28.71$ \\
LiT & $(60) 9.84$ & (98) 9.26 & (59) 8.31 & (99) 10.33 \\
LiF & $(8) 1.31$ & $(73) 6.90$ & $(31) 4.37$ & (50) 5.22 \\
VC & $(194) 31.80$ & $(132) 12.48$ & $(153) 21.55$ & (173) 18.06 \\
Rooting & - & (51) 4.82 & (20) 2.82 & (31) 3.24 \\
BB & - & (6) 0.57 & (3) 0.42 & (3) 0.31 \\
\hline
\end{tabular}

IC: individual cage; CP: collective pen; LF: low fiber; HF: high fiber; AS: absence of stereotypy; DW: drinking water; LiT: licking trough; LiF: licking floor; VC: vacuum chewing; BB: bar biting. The number of observations is given in parentheses.

In general, stereotyped behavior (trough licking, floor licking, and vacuum chewing) were more frequent in animals housed in individual cages, corresponding to $42.95 \%$ of total observation time, compared to those housed in collective pens $(28.64 \%)$, probably due to the small space in the former. Similar results have been reported by Vieuille-Thomas et al. (1995), and Pandorfi et al. (2008). The behavior of rooting solid floor in the absence of any substrate (bedding), demonstrating the need to explore the environment in search of food, characterizes a stereotypy and was not observed in the present study since the assessments were performed up to 3 hours after feeding, when the sensation of satiety prevents the expression of this behavior. 
Using behavioral analysis based on video image recordings, Pandorfi et al. (2011) found a lower incidence of behaviors resulting from environmental stress, stereotypies and aggressive interactions when pregnant sows were housed in collective pens compared to those kept in individual cages. In general, stereotyped behaviors were $3.8 \%$ more frequent in the individual cage housing system, corresponding to $14.12 \%$ of total observation time, compared to collective pens (due to the small space in the former).

Gentilini et al. (2003), studying the behavior and stereotypy of pregnant sows housed in cages and collective pens and fed a HF or LF diet, found no association between diet and the expression of stereotypies in animals housed in collective pens. The LF diet fed to females housed in cages was associated with a higher frequency of licking the floor and/or trough and wind sucking. Housing in cages resulted in a higher frequency of licking the floor and/ or trough and vacuum chewing, irrespective of diet. The stereotypy wind sucking was more frequent in females kept in cages than in those housed in pens when fed the LF diet. According to these authors, the administration of a diet rich in fiber increased the satiety of females kept in cages, rendering them calmer so that they adopted the lying position and presented fewer stereotypies. In contrast, females receiving the diet with low crude fiber content expressed their dissatisfaction or disappointment with food by remaining in the standing or sitting position or by expressing stereotypies, probably waiting for more food.

The low well-being of females housed in cages supports the observations of Vieuille-Thomas et al. (1995) who studied the influence of housing system on the expression of stereotypies in pregnant sows. The authors observed a higher frequency of stereotypies among females housed in individual pens $(92.6 \%)$ compared to those housed in collective pens $(66.2 \%)$.
The reduced restlessness of sows maintained in cages with increasing dietary fiber content, expressed as postural changes and reduced expression of stereotyped behavior after morning feeding, confirms the results of other studies which measured the frequency and type of stereotypy of animals receiving diets with different sources and levels of fibers (Danielsen and Vestergaard 2001).

Fibrous ingredients that possess a high water retention capacity are highly effective in satisfying feeding motivation (Kambashi et al. 2014). According to Robert et al. (1997), females receiving less bulky diets finished their meal before the postprandial glucose and insulin peak, suggesting that the motivation to eat had not yet ceased. Females fed fibrous diets finished their meal at the time of the peak or thereafter. According to Close and Cole (2004), stereotyped behaviors might be more apparent in restricted environments and can be minimized by increasing dietary fiber content and feeding frequency.

Salivary cortisol levels did not differ significantly $(\mathrm{P}>0.05)$ between the housing systems or diets offered, with levels of 0.9588 and $1.0069 \mathrm{ng} \mathrm{ml}^{-1}$ for individual and collective pens, respectively, and of 1.1650 and $0.7875 \mathrm{ng} \mathrm{ml}^{-1}$ for the LF and HF diets, respectively. The cortisol levels were low, indicating that the animals were not stressed during the period and times evaluated.

Dalla Costa et al. (2009) evaluated the effect of pre-slaughter management on cortisol concentration of heavy female pigs and observed that salivary cortisol concentration of pigs during pre-slaughter management promoted an increase in its concentration. On the farm, cortisol concentration was $0.112 \mu \mathrm{g} \mathrm{dL} \mathrm{dL}^{-1}$. This value decreased to $0.088 \mu \mathrm{g} \mathrm{dL} \mathrm{d}^{-1}$ immediately after departure and higher values $\left(0.205 \mu \mathrm{g} \mathrm{dL}^{-1}\right)$ were detected immediately after arrival of the animals at the slaughterhouse. However, the mean salivary cortisol concentration of pigs was $0.347 \mu \mathrm{g} \mathrm{dL}^{-1}$ before slaughter. 
Except for weights at breeding and farrowing and body condition at breeding, which differed between the two housing systems, no significant differences were observed for the other parameters studied and there was no significant interaction between housing systems and diets (Table IX).

TABLE IX

Mean performance parameters during gestation and maternity of sows according to housing system and diet.

\begin{tabular}{ccccc}
\hline \multirow{2}{*}{ Performance } & \multicolumn{2}{c}{ System } & \multicolumn{2}{c}{ Diet } \\
\cline { 2 - 5 } & IC & CP & LF & HF \\
\hline WB (kg) & $247.25^{\mathrm{a}}$ & $201.63^{\mathrm{b}}$ & $234.75^{\mathrm{a}}$ & $214.13^{\mathrm{a}}$ \\
WF (kg) & $284.50^{\mathrm{a}}$ & $235.25^{\mathrm{b}}$ & $265.63^{\mathrm{a}}$ & $254.13^{\mathrm{a}}$ \\
WGBF (kg) & $37.25^{\mathrm{a}}$ & $33.63^{\mathrm{a}}$ & $30.88^{\mathrm{a}}$ & $40.00^{\mathrm{a}}$ \\
BCB & $3.56^{\mathrm{a}}$ & $2.44^{\mathrm{b}}$ & $2.81^{\mathrm{a}}$ & $3.19^{\mathrm{a}}$ \\
BCF & $3.75^{\mathrm{a}}$ & $3.19^{\mathrm{a}}$ & $3.44^{\mathrm{a}}$ & $3.50^{\mathrm{a}}$ \\
BFB (mm) & $13.62^{\mathrm{a}}$ & $12.50^{\mathrm{a}}$ & $13.25^{\mathrm{a}}$ & $12.88^{\mathrm{a}}$ \\
BFF (mm) & $23.87^{\mathrm{a}}$ & $18.75^{\mathrm{a}}$ & $20.38^{\mathrm{a}}$ & $22.25^{\mathrm{a}}$ \\
LB & $10.12^{\mathrm{a}}$ & $10.25^{\mathrm{a}}$ & $11.12^{\mathrm{a}}$ & $9.25^{\mathrm{a}}$ \\
BW (kg) & $1.70^{\mathrm{a}}$ & $1.74^{\mathrm{a}}$ & $1.72^{\mathrm{a}}$ & $1.71^{\mathrm{a}}$ \\
NW & $8.87^{\mathrm{a}}$ & $8.87^{\mathrm{a}}$ & $9.25^{\mathrm{a}}$ & $8.50^{\mathrm{a}}$ \\
WW (kg) & $7.02^{\mathrm{a}}$ & $7.59^{\mathrm{a}}$ & $6.87^{\mathrm{a}}$ & $7.74^{\mathrm{a}}$ \\
FC & $8.45^{\mathrm{a}}$ & $8.8^{\mathrm{a}}$ & $10.11^{\mathrm{a}}$ & $7.14^{\mathrm{a}}$ \\
\hline
\end{tabular}

IC: individual cage; CP: collective pen; LF: low fiber; HF: high fiber; WB: weight at breeding; WF: weight at farrowing; WGBF: weight gain from breeding to farrowing; BCB: body condition at breeding; $\mathrm{BCF}$ : body condition at farrowing; $\mathrm{BFB}$ : backfat thickness at breeding; BFF: backfat at farrowing; LB: live born piglets: BW: birthweight; NW: number of weaned piglets; WW: weaning weight; FC: feed conversion. Mean values in the same row followed by different superscript letters differ significantly by the Tukey test $(\mathrm{P}<0.01)$.

The birth weight of the piglets ranged from 1.70 to $1.74 \mathrm{~kg}$, regardless of housing system or diet. Thus, the litter consisted of piglets with a uniform weight, permitting better development until weaning. In the study of Pandorfi et al. (2008), the birthweight of piglets born to dams housed in individual gestation crates was $1.19 \mathrm{~kg}$ and that of piglets born to dams housed in collective pens was $1.23 \mathrm{~kg}$, guaranteeing weaning at 21 days of age at a weight of 5.11 and $5.33 \mathrm{~kg}$, respectively.

Gentilini et al. (2004) evaluated the productive performance of gilts fed a gestation diet with a low $(7 \%)$ or high $(35 \%)$ level of soybean hulls that contained 4.5 and $13.1 \%$ crude fiber, respectively. Females fed the LF diet were heavier $(214.70 \mathrm{~kg})$ than those fed the HF diet $(210.40 \mathrm{~kg})$ at 110 days of gestation. The number of piglets born alive (9.97 and 10.65) was similar for both treatments. The mean birth weight was higher for piglets born to females fed the LF diet (1.44 kg) compared to those born to females fed the HF diet $(1.36 \mathrm{~kg})$. The weight or number of piglets at weaning was not affected by the treatment, in agreement with the observations of other authors (Danielsen and Vestergaard 2001).

\section{CONCLUSION}

Pregnant sows reared in collective pens and fed HF diets exhibit better physiological responses, indicating greater comfort and better animal welfare.

The environmental variables were close to the comfort zone of the animals. In addition to providing a more comfortable environment, housing pigs in collective pens reduced stereotypy, permitting the sows to express a more natural behavior.

The HF diet did not interfere with female productive performance. Tifton hay can therefore be indicated as an alternative for the formulation of sow diets to improve animal welfare.

\section{ACKNOWLEDGMENTS}

The authors are indebted to Prof. Dr. Messias Alves Trindade Neto for revision of the manuscript.

\section{RESUMO}

Foram utilizadas dezesseis matrizes suínas gestantes, submetidas a um delineamento inteiramente ao acaso em esquema fatorial $2 \times 2$ onde foram estudados dois sistemas de criação (gaiolas individuais e baias coletivas) e duas dietas (baixo $(\mathrm{BF}=2,67 \%)$ e alto $(\mathrm{AF}=$ 13,14\%) nível de fibra bruta. Foram avaliados os índices fisiológicos, comportamentais, ambientais e hormonais, como também os parâmetros produtivos e reprodutivos, tais como: ganho de peso, consumo de ração, conversão alimentar da porca e dos leitões, número de leitões 
nascidos vivos e mortos, número e peso ao desmame e a espessura de toucinho das porcas. As fêmeas gestantes quando criadas em baias coletivas e com alta fibra na ração apresentaram melhores respostas fisiológicas, indicando melhor conforto e bem estar animal, e as variáveis ambientais apresentaram-se próximas à zona de conforto dos animais. O sistema de criação em baias coletivas além de proporcionar melhor conforto aos animais diminuiu a estereotipia, permitindo que as porcas manifestassem um comportamento mais próximo do natural. A dieta com alto nível de fibra não interferiu no desempenho produtivo das fêmeas, sendo, portanto indicado o feno de tífton na formulação da dieta das porcas como alternativa de melhorar o bem estar-animal.

Palavras-chave: suíno, bem-estar animal, enriquecimento ambiental, sistemas de criação.

\section{REFERENCES}

ALBRIGHT LD. 1990. Environmental control for animals and plants. St. Joseph, MI: ASAE Textbook, 45 p.

ANIL L, ANIL SS AND DEEN J. 2002. Relationship between postural behavior and gestation stall dimensions in relation to sow size. Appl Anim Behav Sci 77:173-181.

Buffington DE, Collasso-Arocho A, CANTON GH AND PITT D. 1981. Black globe humidity index (BGHI) as comfort equation for dairy cows. T ASAE 24:711-714.

Cassar G, Kirkwood RN, Seguin MJ, Zanella AJ AND FRIENDSHIP RM. 2008. Influence of stage of gestation at grouping and presence of boars on farrowing rate and litter size of group-housed sows. J Swine Health Prod 16:81-85.

Che L, Feng D, Wu D, FAng Z, Lin Y AND YAN T. 2011. Effect of dietary fibre on reproductive performance of sows during the first two parities. Reprod Domest Anim 46: 1061-1066.

Close WH AND COLE DJA. 2004. Estrategias prácticas de alimentación. In Close, W.H.; Cole, D.J.A. Nutrición de Cerdas y Verracos. Alltech de México: Codigrafic S.A., $1^{\mathrm{a}}$ ed., p. 299-340.

Cordeiro MB, Tinôco IFF, Oliveira PAV, MENEGAli I, GUIMARÃES MCC, BAÊTA FC AND SILVA JN. 2007. Effect of different raising systems on the thermal environment comfort and swine productive performance under spring conditions. Rev Bras Zootecn 36: 1597-1602.

CORRÊA EK, BIANCHI I, UlgUIM RR, CORRÊA MN, GILTURNES C AND LUCIA JÚNIOR T. 2008. Effects of different litter depths on environmental parameters and growth performance of growing finishing pigs. Cienc Rural 39: 838-843.
Dalla Costa OA, LudKe JV, COLdebella A, Kich JD, COSTA MJRP, Faucitano L, Peloso JV and Roza DD. 2009. Effect of pre-slaughter management on physiological parameters of heavy-weight female pigs. Cienc Rural 39: 852-858.

DANIELSEN V AND VestergaARD EM. 2001. Dietary fibre for pregnant sows: effect on performance and behaviour. Anim Feed Sci Tech 90: 71-80.

GENTILINI FP, DALLANORA CH, BERNARDI ML, WENTZ I AND BORTOLOZZO FP. 2003. Behaviour of pregnant gilts fed low or high fiber diets and maintained in crates or stalls. Arq Bras Med Vet Zoo 55: 599-605.

Gentilini FP, Dallanora D, Peixoto CH, Bernardi ML, Wentz I AND BorTolozzo FP. 2004. Productive performance of gilts fed gestation diets with low or high soybean hulls level. Cienc Rural 34: 1177-1183.

GOMES JDF, FUKUSHIMA RS, PUTRINO SM, GROSSKLAUS C AND LIMA GJMM. 2006. Effects of increasing neutral detergent fiber in swine diets on the morphology of digestive and non-digestive organs. Braz J Vet Res Anim Sci 43: 202-209.

GONÇALVES RG AND PALMEIRA EM. 2006. Suinocultura Brasileira. Observ Econom Latin 71: 34-40.

Kambashi B, Boudry C, Picron P AND Bindelle J. 2014. Forage plants as an alternative feed resource for sustainable pig production in the tropics: a review. Animal 1:1-14. doi:10.1017/S1751731114000561.

Mendes AS, Moura DJ, NÄÄS IA AND BENDER JR. 2013. Natural ventilation and surface temperature distribution of piglet crate heated floor. Arq Bras Med Vet Zoo 65: 477-484.

PANDORFI H, Silva IJO AND PIEDAde SMS. 2008. Thermal comfort for pregnant sows housed in individual and group stalls. Rev Bras Eng Agric Ambient 12: 326-332.

PANDORFI H, Silva IJO, SARnighausen VCR, Vieira FMC, NASCIMENTO ST AND GUISELINI C. 2011. Use of artificial neural networks on the prediction of zootechnical indexes on gestation and farrowing stages of swines. Rev Bras Zootecn 40: 676-681.

ROBERT S, RUSHEN J AND FARMER C. 1997. Effets d'un ajout de fibres végétales au régime alimentaire des cochettes sur le comportement, le rythme cardiaque et les concentrations sanguines de glucose et d'insuline au moment du repas. Journées Rech Porcine en France 29: 161-166.

SANT'ANNA AC AND PARANHOS DA COSTA MJR. 2010. Avaliação do bem-estar de animais de produção. Cienc Vet Trop 13: 29-35.

SAS InSTITUTE. 2001. SAS/STAT software: changes and enhancements through release 8.02. Cary: Statistical Analysis System Institute, $1167 \mathrm{p}$.

Vieuille-Thomas C, Le PAPE G AND Signoret JP. 1995. Stereotypies in pregnant sows: Indication of influence of the housing system on the patterns expressed by the animals. Appl Anim Behav Sci 44: 19-27.

Young M AND AHERnE F. 2005. Monitoring and maintaining sow condition. Advan Pork Prod 16: 299-313. 
